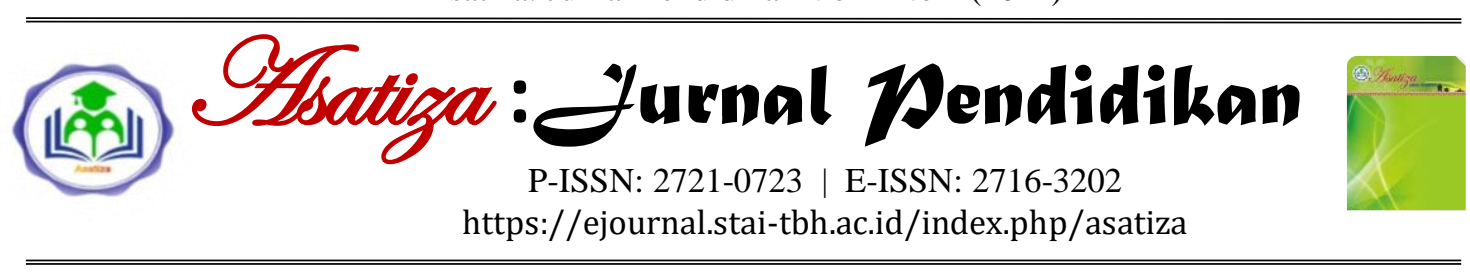

\title{
Implementasi Pilar-Pilar Pendidikan UNESCO
}

\author{
*Cindy Priscilla ${ }^{1, a}$, Deddy Yusuf Yudhyarta ${ }^{2, b}$ \\ ${ }^{1,2}$ STAI Auliaurrasyidin Tembilahan, Indragiri Hilir, Indonesia

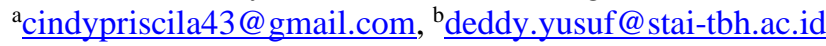

\begin{tabular}{|c|c|}
\hline $\begin{array}{l}\text { INFORMA } \\
\text { ARTIKEL }\end{array}$ & \\
\hline Histori Art & ikel: \\
\hline Diterima & : 18/12/2020 \\
\hline Direvisi & : 24/12/2020 \\
\hline Disetujui & $26 / 12 / 2020$ \\
\hline Diterbitkan & : 23/01/2021 \\
\hline
\end{tabular}

Keywords:

UNESCO, education, pillar

\section{Kata Kunci:}

UNESCO, pendidikan, pilar

\begin{tabular}{l} 
DOI: \\
https://doi.org/10.46963/ \\
asatiza.v2i1.258 \\
\hline
\end{tabular}

*Correspondence

Author:

cindypriscila43@gmail.c

\begin{abstract}
This study aimed to determine the implementation of UNESCO's educational pillars as well as to find out its inhibiting factors at State Vocational High School 1 Tembilahan. This study was a qualitative descriptive study, the proportionate stratified random sampling toward 90 selected students used to gather the data through questionnaires, interviews, and documentation. The result showed that the percentage of the implementation was at $66.37 \%$ (Good). Meanwhile, the inhibiting factors in the implementation were the differentiation of students and limited time allocation.
\end{abstract}

\begin{abstract}
Abstrak
Penelitian ini bertujuan untuk mengetahui bagaimana implementasi pilarpilar pendidikan UNESCO dan mengetahui faktor penghambat Implementasi Pilar-Pilar tersebut di Sekolah Menengah Kejuruan Negeri 1 Tembilahan. Jenis penelitian ini adalah penelitian deskriptif kualitatif, sampel dalam penelitian ini menggunakan proportionate stratified random sampling berjumlah 90 orang. Teknik pengumpulan data melalui angket, wawancara dan dokumentasi. Berdasarkan hasil analisa data menunjukkan bahwa persentasi implementasi pilar UNESCO berada pada angka 66,37\% dengan kategori baik, adapun faktor penghambat dalam Implementasi pilar-pilar pendidikan UNESCO di SMKN 1 Tembilahan yaitu ragam peserta didik dan alokasi waktu yang terbatas.
\end{abstract}

\section{Cara mensitasi artikel:}

Priscilla, C., \& Yudhyarta, D. Y. (2021). Implementasi pilar-pilar pendidikan UNESCO. Asatiza: Jurnal Pendidikan, 2(1), 64-76. https://doi.org/10.46963/asatiza.v2i1.258.

\section{PENDAHULUAN}

Pendidikan merupakan salah satu kebutuhan pokok dalam kehidupan manusia yang berfikir bagaimana menjalani kehidupan dunia ini dalam rangka mempertahankan hidup dalam hidup dan penghidupan manusia yang mengemban tugas dari Sang Khalik untuk beribadah.

Manusia sebagai makhluk yang diberikan kelebihan oleh Allah SWT dengan suatu bentuk akal pada diri manusia yang tidak dimiliki makhluk
Allah yang lain dalam kehidupannya, bahwa untuk mengolah akal pikirannya diperlukan suatu pola pendidikan melalui proses pembelajaran. (Hafid, Ahiri, \& Haq, 2014)

Pilar merupakan penopang atau penyangga dalam sebuah bangunan yang membuat bangunan itu dapat berdiri dengan kukuh. Sistem pendidikan juga memerlukan pilar yang akan menyangga sistem pendidikan yang dilaksanakan agar pendidikan tersebut dapat berjalan dengan baik dalam mencapai tujuan pendidikan. 
Pilar dalam kamus umum adalah tiang penyangga atau penguat dari beton, dan sebagainya, sekaligus dipakai untuk keindahan atau keserasian penunjang untuk kegiatan. M.J. Lavengeveld mengatakan bahwa pendidikan adalah setiap usaha, pengaruh, perlindungan, dan bantuan yang diberikan kepada anak didik yang bertujuan pada pendewasaan anak itu. Dalam Kamus Besar Bahasa Indonesia, kata pilar diartikan sebagai tiang penyangga (terbuat dari besi atau beton). Kata pilar dalam bahasa Inggris berarti pillars sama artinya dengan pilar dalam bahasa Indonesia.

Eksistensi pilar dalam berbagai hal bias dikatakan sangat pending perannya sebagai penopang agar menjadi sesuatu yang utuh (unity). Bangunan atau rumah berangkat dari fondasi yang dilengkapi dengan pilar agar atap bias berdiri kukuh dan tidak mudah roboh sehingga tampak menjadi lengkap dan melengkapi. (Syafril \& Zen, 2007).

Hal ini juga terlihat dari kondisi zaman yang cepat berubah, terutama di bidang teknologi dan informasi sehingga visi paradigma pendidikan harus relevan yang kemudian diturunkan ke dalam metode pembelajaran. Yaitu mengubah paradigma teaching (mengajar) menjadi learning (belajar). Dengan perubahan ini proses pendidikan menjadi proses bagaimana belajar bersama antarguru dan anak didik. Guru dalam konteks ini termasuk dalam proses belajar. Sehingga lingkungan sekolah jadi learning society (masyarakat belajar).

Sebagai objek sekaligus subjek pendidikan, manusia menjadi titik sentral dalam proses belajar yang mengarah pada tujuan pendidikan. Manusia belajar dari apa saja di sekitarnya untuk survive sekaligus pengembangan potensi diri, lahir dari ketidaktahuan dari rahim seorang ibu dan dibekali penglihatan, pendengaran dan akal untuk digunakan dalam tugasnya sebagai khalifatullah fil ardh. Berangkat dari sinilah, paradigma learning ini diusung sebagai pilar pendidikan untuk kepentingan manusia dengan perubahan zaman dan ini berangkat dari paradigma belajar.

Berdasarkan paradigma di atas, dapat disimpulkan bahwa pilar pendidikan adalah tiang atau penunjang dari suatu kegiatan usaha, pengaruh, perlindungan, dan bantuan yang akan diberikan kepada anak didik yang bertujuan untuk pendewasaan anak. (Syafril \& Zen, 2007).

Pada prinsipnya apabila ingin berhasil melaksanakan tugas-tugasnya, maka pendidikan hendaknya diatur di sekitar empat jenis belajar yang fundamental sifatnya yang sepanjang kehidupan seseorang dapat dikatakan sebagai sendi atau sokoguru pengetahuan: belajar berbuat, sehingga mampu bertindak kreatif di lingkungannya, belajar hidup bersama, sehingga mampu berperan serta dan bekerja sama dengan orangorang lain di dalam semua kegiatan manusia, dan belajar menjadi seseorang, suatu kemajuan penting yang merupakan kelanjutan dari ketiga sendi di atas. Tentulah keempat jalan pengetahuan ini merupakan satu kesatuan, karena banyak titik temu, perpotongan dan pertukaran di antaranya. (Taniredja, 2016)

Kualitas dapat dimaknai dengan istilah mutu atau keefektifan. Secara definitif, efektivitas dapat dinyatakan 
sebagai tingkat keberhasilan dalam mencapai tujuan atau sasarannya. Efektivitas merupakan suatu konsep yang sangat penting karena mampu memberikan gambaran mengenai keberhasilan seseorang dalam mencapai sasaran atau tingkat pencapaian tujuantujuan. Sementara itu, belajar dikatakan sebagai komunikasi terencana yang menghasilkan perubahan sikap, keterampilan dan pengetahuan dalam hubungan dengan sasaran khusus yang berkaitan dengan pola perilaku individu untuk mewujudkan tugas atau pekerjaan tertentu. Dengan demikian, efektivitas belajar adalah tingkat pencapaian tujuan pembelajaran, termasuk pembelajaran seni. Pencapaian tujuan tersebut berupa peningkatan pengetahuan dan keterampilan serta pengembangan sikap melalui proses pembelajaran. (Kodir, 2011)

Akan tetapi di Sekolah Menengah Kejuruan Negeri 1 Tembilahan masih ditemukan fakta bahwa guru cenderung hanya menggunakan pada buku paket tertentu saja dan tidak menggunakan buku referensi yang lainnya sehingga pengetahuan siswa hanya terbatas pada buku itu saja, kurangnya keterampilan dalam mengaplikasikan ilmu pengetahuan yang diperoleh, kurangnya kemampuan dalam bersosialisasi dengan masyarakat, serta siswa yang belum mampu mengembangkan diri secara maksimal.

UNESCO dalam Abdul Kodir pada bukunya Strategi Belajar Mengajar mengatakan dalam mencapai efektivitas belajar ini, menetapkan empat pilar pendidikan yang harus diperhatikan, yaitu Learning to Know (Belajar Mengetahui),
Learning to do (Belajar Melakukan Sesuatu), Learning to Live Together (Belajar Hidup Bersama), Learning to be (Belajar Menjadi Sesuatu). (Kodir, 2011).

\section{METODE}

Jenis penelitian ini menggunakan Penelitian Deskriptif Kualitatif. Penelitian Deskriptif adalah suatu bentuk penelitian yang paling dasar ditujukan untuk mendeskripsikan atau menggambarkan fenomena-fenomena yang ada, baik fenomena yang bersifat alamiah ataupun rekayasa manusia. (Sukmadinata, 2012). Penelitian kualitatif dapat diartikan sebagai metode penelitian yang berlandaskan filsafat postpositivisme, digunakan untuk meneliti pada kondisi objek yang alamiah. (Sugiyono, 2015). Subjek dalam penelitian ini adalah siswa kelas X dan XI, waka kurikulum, dan 1 orang guru mata pelajaran Sekolah Menengah Kejuruan Negeri 1 Tembilahan. Objek penelitian in adalah Implementasi pilar-pilar pendidikan di Sekolah Menengah Kejuruan Negeri 1 Tembilahan.

Diketahui jumlah populasi kelas $\mathrm{X}$ dan XI sebesar $\mathrm{N}=908$ siswa dan tingkat presisi yang ditetapkan sebesar $\mathrm{d}^{2}=10 \%$ $(0,1)$. Untuk mengetahui jumlah sampel dalam penelitian ini maka digunakan rumus sebagai berikut:

$$
\begin{aligned}
n & =\frac{\mathrm{N}}{\mathrm{Nd}^{2}+1} \\
n & =\frac{908}{908(0,1)^{2}+1} \\
n & =\frac{908}{(908)(0,01)+1} \\
n & =\frac{908}{10,08} \\
n & =90,07
\end{aligned}
$$


$\mathrm{n}=90,07$ dibulatkan menjadi 90

Setelah diketahui jumlah sampel secara keseluruhan yaitu 90 siswa, maka langkah selanjutnya adalah mengalokasikan atau menyebarkan satuan-satuan sampel ini kepada setiap kelas dengan menggunakan pengambilan sampel secara proportionate stratified random sampling (pengambilan sampel bertingkat) memakai rumus alokasi proporsional dengan rumus :

$\mathrm{ni}=(\mathrm{NI}: \mathrm{N}) . \mathrm{n}$

Kelas X $=467: 908 \times 90=46,28=46$

Kelas XI $=441: 908 \times 90=43,71=44$

Jumlah $=908$ Siswa $=90$ Siswa

Maka setiap pengambilan sampel pada kelas $\mathrm{X}$ adalah 46 siswa/siswi, kelas XI adalah 44 siswa/siswi.

Adapun teknik pengumpulan data yang digunakan dalam penelitian ini adalah sebagai berikut: Angket. Wawancara dan dokumentasi. Data dalam penelitian ini dianalisis dan dideskripsikan dengan pola fikir induktif deduktif. Selanjutnya data kualitatif akan diubah kedalam angka dengan cara mempresentasekannya sesuai dengan frekuensi yang didapat.

\section{HASIL DAN PEMBAHASAN Pengertian Pilar}

Pilar merupakan penopang atau penyangga dalam sebuah bangunan yang membuat bangunan itu dapat berdiri dengan kukuh. Sistem pendidikan juga memerlukan pilar yang akan menyangga sistem pendidikan yang dilaksanakan agar pendidikan tersebut dapat berjalan dengan baik dalam mencapai tujuan pendidikan.

Pilar dalam kamus umum adalah tiang penyangga atau penguat dari beton, dan sebagainya, sekaligus dipakai untuk keindahan atau keserasian penunjang untuk kegiatan. M.J. Lavengeveld mengatakan bahwa pendidikan adalah setiap usaha, pengaruh, perlindungan, dan bantuan yang diberikan kepada anak didik yang bertujuan pada pendewasaan anak itu. Dalam Kamus Besar Bahasa Indonesia, kata pilar diartikan sebagai tiang penyangga (terbuat dari besi atau beton). Kata pilar dalam bahasa Inggris berarti pillars (sama artinya dengan pilar dalam bahasa Indonesia).

Eksistensi pilar dalam berbagai hal bias dikatakan sangat pending perannya sebagai penopang agar menjadi sesuatu yang utuh (unity).Bangunan atau rumah berangkat dari fondasi yang dilengkapi dengan pilar agar atap bias berdiri kukuh dan tidak mudah roboh sehingga tampak menjadi lengkap dan melengkapi. (Syafril \& Zen, 2007).

Hal ini juga terlihat dari kondisi zaman yang cepat berubah, terutama di bidang teknologi dan informasi sehingga visi paradigma pendidikan harus relevan yang kemudian diturunkan ke dalam metode pembelajaran yaitu mengubah paradigma teaching (mengajar) menjadi learning (belajar). Dengan perubahan ini proses pendidikan menjadi proses bagaimana belajar bersama antar guru dan anak didik. Guru dalam konteks ini termasuk dalam proses belajar. Sehingga lingkungan sekolah jadi learning society (masyarakat belajar).

Sebagai objek sekaligus subjek pendidikan, manusia menjadi titik sentral dalam proses belajar yang mengarah pada tujuan pendidikan. Manusia belajar dari apa saja di sekitarnya untuk survive sekaligus pengembangan potensi diri, lahir 
dari ketidaktahuan dari rahim seorang ibu dan dibekali penglihatan, pendengaran dan akal untuk digunakan dalam tugasnya sebagai manusia. Berangkat dari sinilah, paradigma learning ini diusung sebagai pilar pendidikan untuk kepentingan manusia dengan perubahan zaman dan ini berangkat dari paradigma belajar.

\section{Pengertian Pendidikan}

Pendidikan merupakan salah satu kebutuhan pokok dalam kehidupan manusia yang berfikir bagaimana menjalani kehidupan dunia ini dalam rangka mempertahankan hidup dalam hidup dan penghidupan manusia yang mengemban tugas dari Sang Khalik untuk beribadah.

Manusia sebagai makhluk yang diberikan kelebihan oleh Allah SWT dengan suatu bentuk akal pada diri manusia yang tidak dimiliki makhluk Allah yang lain dalam kehidupannya, bahwa untuk mengolah akal pikirannya diperlukan suatu pola pendidikan melalui proses pembelajaran. (Hafid, Ahiri, \& Haq, 2014).

\section{Pilar Pendidikan UNESCO}

Pilar pendidikan adalah tiang atau penunjang dari suatu kegiatan usaha, pengaruh, perlindungan, dan bantuan yang akan diberikan kepada anak didik yang bertujuan untuk pendewasaan anak. (Syafril \& Zen, 2007).

\section{United Nations Educational,} Scientific and Cultural Organization, disingkat UNESCO merupakan badan khusus PBB yang didirikan pada tahun 1945. (Wikipedia, 2019). UNESCO berdiri dengan ditandatanganinya konstitusi UNESCO di London pada tanggal 16 November 1945. Suasana keprihatinan atas terjadinya perang dunia pertama dan kedua secara berturut-turut yang kurang dari masa satu generasi dinyatakan sebagai tujuan dasar dari pendirian dan sekaligus menjadi moto organisasi ini yang tertuang dalam kalimat terkenal berikut: since wars begin in the mind of men, it is in the minds of men that the defenses of peace must be constructed (oleh karena perang diawali dari pikiran manusia, maka dalam pikiran manusialah upaya menjaga perdamaian dibangun).

Dalam melaksanakan tugasnya, UNESCO meletakkan prioritasnya pada masalah kesetaraan gender, pendidikan, dan pengembangan Negara-negara Afrika. UNESCO telah memiliki rencana aksi kesetaraan gender UNESCO tahun 20142021 yang memberikan perhatian khusus pada kasus-kasus kekerasan terhadap perempuan, terutama di wilayah konflik.UNESCO berusaha mengatasi masalah tersebut sesuai dengan tugas UNESCO, yaitu dengan memberikan pendidikan. (Kemendikbud, 2018).

Menurut UNESCO dalam buku Belajar dan Pembelajaran oleh Aunurrahman, Komisi Pendidikan untuk Abad XXI melihat bahwa pendidikan sesungguhnya adalah belajar (learning). Selanjutnya dikemukakan bahwa pendidikan bertumpu pada empat pilar, yaitu; (1) learning to know (Belajar Mengetahui), (2) learning to do (Belajar Melakukan Sesuatu), (3) learning to live together (Belajar Hidup Bersama), (4) learning to be (Belajar Menjadi Sesuatu) (Aunurrahman, 2014).

Jenis-jenis Pilar Pendidikan UNESCO: 
Learning to Know (Belajar Mengetahui)

Pembelajaran yang berlangsung di sekolah umumnya dimaksudkan mendorong siswa memperoleh pengetahuan secara terstruktur, di samping penguasaan alat belajar. Dengan demikian pembelajaran merupakan sarana sekaligus sebagai upaya mencapai tujuan akhir eksistensi manusia. (Danim, 2010).

Learning to Know (belajar untuk mengetahui), artinya belajar itu harus dapat memahami apa yang dipelajari bukan hanya dihafalkan tetapi harus ada pengertian yang dalam. Hal ini dapat diartikan bahwa siswa harus memiliki pemahaman yang bermakna terhadap proses pendidikan mereka. Siswa diharapkan memahami secara bermakna asal mula teori dan konsep, serta menggunakannya untuk menjelaskan dam memprediksi proses-proses berikutnya. Siswa harus memiliki tujuan dalam belajar, selalu mencari tahu dan menggali hal yang harus diketahuinya, dan mencari cara yang harus ditempuh untuk dapat mengetahui hal-hal tersebut. Hal yang harus digarisbawahi adalah bahwa learning to know tidak sekadar memperoleh pengetahuan tapi juga menguasai teknik memperoleh pengetahuan tersebut. Tidak hanya itu, siswa juga dituntut tidak sekadar mengetahui ilmu tetapi juga sekaligus mengetahui apa yang bermanfaat bagi kehidupan. Pilar ini berperan untuk membentuk generasi penerus bangsa yang memiliki kemampuan intelektual dan akademik yang tinggi. (Syafril \& Zen, 2007).

Learning to know adalah upaya memahami instrumen-instrumen pengetahuan baik sebagai alat maupun sebagai tujuan. Sebagai alat, pengetahuan tersebut diharapkan akan memberikan kemampuan setia orang untuk memahami berbagai aspek lingkungan agar mereka dapat hidup dengan harkat dan martabatnya dalam rangka mengembangkan keterampilan kerja dan berkomunikasi dengan berbagai pihak yang diperlukan. Sebagai tujuan, maka pengetahuan tersebut akan bermanfaat dalam rangka peningkatan pemahaman, pengetahuan serta penemuan di dalam kehidupannya. Upaya-upaya ke arah pemerolehan pengetahuan ini tidak akan pernah ada batasnya, dan masing-masing individu akan secara terus menerus memperkaya pengetahuan dirinya dengan berbagai pengalaman yang ditemukan dalam kehidupannya. Upaya-upaya ini akan berlangsung secara terus menerus yang pada gilirannya melahirkan kembali konsep belajar sepanjang hayat. (Aunurrahman, 2014). Learning to Know bukan sebatas proses belajar di mana peserta didik mengetahui dan memiliki materi informasi sebanyak-banyaknya, menyimpan dan mengingat, namun juga kemampuan untuk dapat memahami makna dibalik materi ajar yang telah diterimanya. (Kodir, 2011).

Belajar mengetahui diperlukan sebagai syarat belajar untuk belajar, melibatkan kekuatan konsentrasi atau pemusatan perhatian, ingatan dan pikiran. Mulai anak semasa kecil, teristimewa di masyarakat-masyarakat yang dipengaruhi oleh televisi, kaum muda harus belajar memusatkan pada benda-benda dan manusia. 
Menggunakan ingatan merupakan penawar yang penting daripada dibanjiri oleh informasi sejenak yang ditayangkan oleh media. Adalah berbahaya untuk membayangkan bahwa ingatan tidak diperlukan lagi karena kemampuan kita yang sudah hebat untuk menyimpan dan mengedarkan informasi. Kita harus selektif tentang apa yang akan kita pelajari dari luar kepala, tetapi kemampuan mental manusia yang khas untuk mengingat asosiasi yang tidak dapat dikurangi ke bentuk berfungsi secara otomatis haruslah dipupuk dengan baik-baik. Semua spesialis bersepakat, bahwa ingatan harus dilatih sejak anak semasa kecil dan tidaklah tepat untuk dihapuskan sekolah latihan atau soal tradisional tertentu yang memang membosankan.

Memperoleh pengetahuan adalah suatu proses yang tidak pernah berakhir dan dapat diperkaya dengan semua bentuk pengalaman. Dalam pengertian ini, hal itu sudah semakin terjalin dengan pengalaman kerja, karena hakikat pekerjaan sudah menjadi kurang rutin. Pendidikan permulaan dapat dipandang berhasil jika sudah diberikannya motivasi dan fondasi yang diperlukan untuk meneruskan proses belajar sepanjang hayat, baik dalam pekerjaan maupun diluarnya.

Belajar mengetahui, maksudnya dengan memadukan pengetahuan umum yang cukup luas dengan kesempatan untuk bekerja secara mendalam pada sejumlah kecil mata pelajaran.Ini juga berarti belajar untuk belajar, sehingga memperoleh keuntungan dari kesempatan-kesempatan pendidikan yang disediakan sepanjang hayat. (Taniredja, 2016).
Seorang guru seyogianya berfungsi sebagai fasilitator dalam pembelajaran. Guru dituntut untuk berperan aktif sebagai teman sejawat dalam berdialog dengan siswa, dalam mengembangkan penguasaan pengetahuan maupun ilmu tertentu. (Hamdani, 2011).

Konsep Learning to Know ini menyiratkan makna bahwa pendidik harus mampu berperan sebagai berikut:

1) Guru berperan sebagai sumber belajar

Peran ini berkaitan penting dengan penguasaan materi pembelajaran. Dikatakan guru yang baik apabila ia dapat menguasai materi pembelajaran dengan baik, sehingga benar-benar berperan sebagai sumber belajar bagi anak didiknya.

2) Guru sebagai fasilitator

Guru berperan memberikan pelayanan memudahkan siswa dalam kegiatan proses pembelajaran.

3) Guru sebagai pengelola

Guru berperan menciptakan iklim belajar yang memungkinkan siswa dapat belajar secara nyaman. (Efendi, 2015).

\section{Learning to Do(Belajar Melakukan Sesuatu)}

Learning to do merupakan konsekuensi dari Learning to know. (Kodir, 2011). Learning to do lebih ditekankan pada bagaimana mengajarkan anak-anak untuk mempraktikkan segala sesuatu yang telah dipelajarinya dan dapat mengadaptasikan pengetahuanpengetahuan yang telah diperolehnya tersebut dengan pekerjaan-pekerjaan di masa depan. Memperhatikan secara cermat kemajuan-kemajuan serta perubahan-perubahan yang terjadi, maka 
pendidikan tidak cukup hanya dipandang sebagai transmisi atau melaksanakan tugas-tugas rutin, akan tetapi harus mengarah pada pemberian kemampuan untuk berbuat menjangkau kebutuhankebutuhan dinamis masa mendatang, karena lapangan kerja masa mendatang akan sangat tergantung pada kemampuan untuk mengubah kemajuan dalam pengetahuan yang melahirkan usaha atau pekerjaan-pekerjaan baru. Hal ini akan menjadi tonggak penting untuk membentuk kemampuan, kemauan serta kesadaran atas berkembangnya ekonomi baru yang berbasis pengetahuan. Sebagaimana juga pada pilar pertama, maka belajar menerapkan sesuatu yang telah diketahui juga harus dilakukan secara terus menerus, karena proses perubahan juga akan berjalan tanpa hentinya. Dengan keinginan yang kuat untuk belajar melakukan sesuatu, maka setiap orang akan terlepas dari tindakantindakan yang tidak memiliki nilai-nilai positif bagi kehidupannya, dan hal ini memiliki arti sangat penting dalam memelihara proses dan lingkungan kehidupan yang memberikan ketenteraman bagi diri orang lain. (Aunurrahman, 2014).

Sekolah sebagai masyarakat belajar hendaknya memfasilitasi siswanya untuk mengaktualisasikan keterampilan yang dimiliki, serta bakat dan minatnya agar Learning to do dapat terealisasi. (Efendi, 2015). Walaupun bakat dan minat anak banyak dipengaruhi unsur keturunan (heredity), tumbuh berkembangnya bakat dan minat bergantung pada lingkungannya. Dewasa ini, keterampilan bisa digunakan menopang kehidupan seseorang, bahkan keterampilan lebih dominan dari ada penguasaan pengetahuan dalam mendukung keberhasilan kehidupan siswa. Untuk itu, pembinaan terhadap keterampilan siswa perlu mendapat perhatian serius. (Hamdani, 2011)

Pendidikan membekali manusia tidak sekadar untuk mengetahui, tetapi lebih jauh terampil berbuat/mengerjakan sesuatu sehingga menghasilkan sesuatu yang bermakna bagi kehidupan. Sasaran pilar kedua ini adalah kemampuan kerja generasi muda untuk mendukung dan memasuki ekonomi industri. (Efendi, 2015)

\section{Learning to Live Together (Belajar Hidup Bersama)}

Learning to live together, pada dasarnya adalah mengajarkan, melatih dan membimbing peserta didik agar mereka dapat menciptakan hubungan melalui komunikasi yang baik, menjauhi prasangka-prasangka buruk terhadap orang lain serta menjauhi dan menghindari terjadinya perselisihan dan konflik. Persaingan dalam misi ini harus dipandang sebagai upaya-upaya yang sehat untuk mencapai keberhasilan, bukan sebaliknya bahwa persaingan justru mengalahkan nilai-nilai kebersamaan bahkan penghancuran orang lain atau pihak lain untuk kepentingan sendiri. Dengan demikian diharapkan kedamaian dan keharmonisan hidup benar-benar dapat diwujudkan.

Tugas pendidikan, baik dalam rangka pembelajaran bagi siswa dan mahasiswa tentang keragaman manusia maupun untuk menanamkan kesadaran diri mereka tentang persamaan dan saling 
ketergantungan semua orang esensinya adalah bagaimana mereka mampu hidup bersama dengan orang lain secara bersahabat dan menyenangkan. Sejak dari anak usia dini, proses dan substansi pembelajaran harus merebut setiap kesempatan untuk mengejar aneka cabang ilmu yang mengarah pada tujuan ini. (Danim, 2010)

Dalam proses pembelajaran,
pengembangan
berkomunikasi yang baik dengan guru dan sesama siswa yang dilandasi sikap saling menghargai harus perlu secara terus menerus dikembangkan di dalam setiap Event pembelajaran. Kebiasaan-kebiasaan untuk bersedia mendengar dan menghargai pendapat rekan-rekan sesama siswa sering kali kurang mendapat perhatian oleh guru, karena dianggap sebagai hal rutin yang berlangsung saja pada kegiatan sehari-hari. Padahal kemampuan ini tidak dapat berkembang dengan baik begitu saja, akan tetapi membutuhkan latihan-latihan yang terbimbing dari guru. Kebiasaankebiasaan saling menghargai yang dipraktikkan di ruang-ruang kelas dan dilakukan secara terus menerus akan menjadi bekal bagi siswa untuk dapat dikembangkan secara nyata dalam kehidupan bermasyarakat. (Aunurrahman, 2014).

Learning to live together ini mengajarkan seseorang untuk hidup bermasyarakat dan menjadi manusia berpendidikan yang bermanfaat baik bagi diri sendiri dan masyarakatnya maupun bagi seluruh umat manusia. (Kodir, 2011).

Salah satu fungsi lembaga pendidikan adalah tempat bersosialisasi dan tatanan kehidupan. Artinya, mempersiapkan siswa untuk hidup bermasyarakat. Situasi bermasyarakat hendaknya dikondisikan di lingkungan pendidikan. Kebiasaan hidup bersama, saling menghargai, terbuka, mandiri, dan menerima perlu ditumbuhkembangkan. (Hamdani, 2011)

Belajar hidup bersama, dengan jalan mengembangkan pengertian akan orangorang lain dan kesadaran atas interdependensi, melaksanakan proyekproyek bersama dan belajar mengelola perselisihan, semangat menghormati nilainilai kemajemukan, saling memahami dan perdamaian. (Taniredja, 2016).

\section{Learning to $B e$ (Belajar Menjadi Sesuatu)}

Learning to be mengandung arti bahwa belajar adalah proses untuk membentuk jati dirinya sendiri. Oleh karena itu, pendidik harus berusaha memfasilitasi peserta didik agar belajar mengaktualisasikan dirinya sendiri sebagai individu yang berkepribadian utuh dan bertanggung jawab sebagai individu sekaligus sebagai anggota masyarakat. (Efendi, 2015).

Learning to be, sebagaimana diungkapkan secara tegas oleh komisi pendidikan, bahwa prinsip fundamental pendidikan hendaklah mampu memberikan kontribusi untuk perkembangan seutuhnya setiap orang, jiwa dan raga, intelegensi, kepekaan, rasa etika, tanggung jawab pribadi dan nilainilai spiritual. Semua manusia hendaklah diberdayakan untuk berpikir mandiri dan kritis dan mampu membuat keputusan sendiri dalam rangka menentukan sesuatu yang diyakini yang harus dilaksanakan. 
Kekhawatiran yang mendalam terhadap terjadinya salah satu pertimbangan mendasar untuk pentingnya penekanan kembali belajar untuk menjadi diri sendiri ini. Oleh sebab itu, melalui kegiatan pembelajaran, setiap siswa harus terus didorong agar mampu memberdayakan dirinya melalui latihan-latihan pemecahan masalah-masalahnya sendiri. Dalam keadaan ini pendidikan dan pembelajaran hendaknya dapat memberikan kekuatan, membekali mampu mengembangkan talenta yang dimilikinya untuk dapat hidup secara layak ditengah-tengah berbagai dinamika dan gejolak kehidupan masyarakat. (Aunurrahman, 2014)

Pengembangan diri secara maksimal erat hubungannya dengan bakat dan minat, perkembangan fisik dan kejiwaan, tipologi pribadi anak, serta kondisi lingkungannya. Bagi anak yang agresif, proses pengembangan diri akan berjalan baik apabila diberi kesempatan cukup luas untuk berkreasi. Sebaliknya, bagi anak yang pasif, peran guru sebagai pengarah sekaligus fasilitator sanga dibutuhkan untuk pengembangan diri siswa secara maksimal. Kemampuan diri yang terbentuk di sekolah secara maksimal memungkinkan siswa untuk mengembangkan diri pada tingkat yang lebih tinggi. (Hamdani, 2011).

Manusia harus tumbuh menjadi dirinya sendiri. Perkembangan manusia, dimulai saat lahir hingga sepanjang hidupnya, adalah sebuah proses dialektika yang didasarkan pada pengetahuan dan hubungan pribadi dengan orang lain. Hal ini mensyaratkan pengalaman pribadi yang sukses. Sebagai sarana pelatihan kepribadian, pendidikan harus menjadi proses yang sangat individual dan pada saat yang sama pengalaman interaksi sosial. (Danim, 2010).

Tujuan perkembangan adalah pemenuhan diri manusia seutuhnya di dalam kekayaan kepribadiannya, kerumitan bentuk-bentuk pengungkapannya dan berbagai komitmennya sebagai perorangan, anggota keluarga dan masyarakat, warga negara dan produsen, penemu teknikteknik dan pemimpin yang arif.

Menurut UNESCO dalam Tukiran Taniredja, pada buku Guru yang Profesional, belajar menjadi seseorang, sehingga dapat mengembangkan kepribadian lebih baik dan mampu bertindak otonomi, membuat pertimbangan dan rasa tanggung jawab pribadi yang semakin besar. Dalam hubungan ini, pendidikan tidak boleh memandang remeh satu aspek pun dari potensi seseorang yang berupa: ingatan, penalaran, rasa estetika, kemampuan fisik dan keterampilan berkomunikasi. (Taniredja, 2016).

Mutu sistem pendidikan nasional masih menjadi suatu permasalahan yang mendasar dalam pencapaian kualitas pendidikan. Peningkatan kualitas pendidikan sebenarnya terus diupayakan seperti peningkatan proses pembelajaran, kualitas guru dan dosen, penyediaan sarana dan prasarana belajar, perbaikan kurikulum, dan perbaikan sistem penilaian.

Berdasarkan UNESCO empat pilar pendidikan tinggi diperlukan untuk melakukan perbaikan dalam pendidikan tinggi. Empat pilar pendidikan tersebut tidak dapat dipisahkan. Peserta didik yang 
learning to know (Belajar mengetahui) berarti dia juga melaksanakan learning to do (Belajar melakukan sesuatu), learning to live together (Belajar hidup bersama), dan learning to be (Belajar menjadi sesuatu).Empat pilar berdasarkan UNESCO tersebut kemudian diuraikan ke dalam indikator-indikator sebagai berikut.

(Yanti \& dkk, 2018).

Tabel 2.1

Indikator Pilar-Pilar Pendidikan UNESCO

\begin{tabular}{|c|c|}
\hline 4 Pilar Pendidikan UNESCO & Indikator 4 Pilar Pendidikan UNESCO \\
\hline Learning to Know (Belajar Mengetahui) & $\begin{array}{ll}\text { - } & \text { Menguasai dan mendapatkan materi } \\
\text { - } & \text { Mencari informasi dari lingkungan sekitar dan } \\
\text { - } & \text { Merespons sumber informasi baru } \\
\text { - } & \text { Mengembangkan rasa ingin tahu } \\
\text { - } & \text { Memanfaatkan sumber belajar }\end{array}$ \\
\hline $\begin{array}{l}\text { Learning to Do (Belajar Melakukan } \\
\text { Sesuatu) }\end{array}$ & $\begin{array}{ll}\text { - } & \text { Mengaitkan pelajaran dengan kompetensi } \\
\text { - } & \text { Menjembatani pengetahuan dan keterampilan } \\
\text { - } & \text { Mengaplikasikan pemahaman dan bertindak secara } \\
\text { - } & \text { kreatif } \\
\text { - } & \text { Meningapatkan problem solving } \\
\end{array}$ \\
\hline $\begin{array}{l}\text { Learning to Live Together } \\
\text { (Belajar Hidup Bersama) }\end{array}$ & $\begin{array}{l}\text { - Menerapkan nilai-nilai kebersamaan } \\
\text { - Memiliki kemampuan untuk hidup bersama dengan } \\
\text { - } \quad \text { Bnak-anak yang berbeda } \\
\text { - }\end{array}$ \\
\hline $\begin{array}{l}\text { Learning to Be (Belajar Menjadi } \\
\text { Sesuatu) }\end{array}$ & $\begin{array}{l}\text { - } \quad \text { Mengenal kekurangan dan kelebihan diri sendiri } \\
\text { - } \quad \text { Menunjukkan sikap percaya diri } \\
\text { - } \quad \text { Memunjukkan kemampuan belajar secara mandiri } \\
\text { - } \quad \text { Belajar menjadi orang yang bertanggung jawab }\end{array}$ \\
\hline
\end{tabular}

Keempat pilar ini merupakan misi dan tanggung jawab yang harus diemban oleh pendidikan. Melalui kegiatan belajar mengetahui, belajar melakukan sesuatu, belajar hidup bersama dan belajar menjadi sesuatu yang didasari keinginan secara sungguh-sungguh maka akan semakin luas wawasan seseorang tentang pengetahuan, tentang nilai-nilai positif, tentang orang lain serta tentang berbagai dinamika perubahan yang terjadi. Ke semuanya ini diharapkan menjadi modal fundamental bagi seseorang untuk mampu mengarahkan dirinya dalam berperilaku positif berpijak pada nilai-nilai yang dia yakini kebenarannya, dan pada gilirannya akan semakin terbuka pikiran untuk melihat fakta-fakta yang benar dan yang salah, sesuatu tindakan yang sesungguhnya merugikan ataupun 
membawa kemajuan bagi diri dan orang lain.

Dari rekapitulasi data diatas, maka dapat diketahui bahwa hasil observasi untuk alternatif "selalu" berjumlah 434, alternatif jawaban "sering" berjumlah 477 , alternatif jawaban "kadang-kadang" 801, alternatif jawaban "tidak pernah" berjumlah 28, untuk memperoleh persentase dari rekapitulasi hasil Implementasi Pilar-Pilar Pendidikan UNESCO di Sekolah Menengah Kejuruan Negeri 1 Tembilahan Untuk mendapatkan nilai $\mathrm{F}$ dengan cara memberikan bobot pada jawaban hasil observasi, sebagaimana berikut:

a. Untuk alternatif jawaban "selalu" dengan bobot 4 sehingga didapatkan hasil 381 X $4=1524$

b. Untuk alternatif jawaban "sering" dengan bobot 3 sehingga didapat hasil 433 X $3=1299$

c. Untuk alternatif jawaban "kadangkadang" dengan bobot 2 sehingga didapat hasil $725 \times 2=1450$

d. Untuk alternatif jawaban "Tidak pernah" dengan bobot 1 sehingga didapat hasil $28 \times 1=28$

Dari kedua hasil tersebut dijumlahkan menjadi nilai $\mathrm{F}$, sehingga $\mathrm{F}=$ $1524+1299+1450+28=4301$

Untuk memperoleh nilai $\mathrm{N}$ dengan menggunakan rumus sebagai berikut :

$\mathrm{N}=$ Jumlah Populasi $\mathrm{X}$ Jumlah Pertanyaan pada Angket $\mathrm{X}$ Skor Tertinggi

$\mathrm{N}=90 \times 18 \times 4$

$\mathrm{N}=6480$
Setelah itu untuk mencari rata-rata persentase sebagai berikut:

$$
\begin{aligned}
& P=\frac{4301}{6480} \times 100 \\
& \mathbf{P}=\mathbf{6 6 , 3 7 \%}
\end{aligned}
$$

Dari hasil rata-rata rekapitulasi diatas dapat disimpulkan bahwa implementasi pilar-pilar pendidikan UNESCO di Sekolah Menengah Kejuruan Negeri 1 Tembilahan dengan persentase $\mathbf{6 6 , 3 7 \%}$ dikategorikan "baik" berada pada interval $61 \%-80 \%$.

Berdasarkan wawancara yang penulis lakukan kepada responden, diperoleh hasil bahwa menurut guru siswa/siswi sudah mampu mengembang kan dirinya secara maksimal seperti mereka sudah mampu beradaptasi dengan cepat di Dunia dan Industri.

\section{SIMPULAN}

Berdasarkan hasil analisis dari hasil yang telah dilakukan maka dapat ditarik kesimpulan bahwa implementasi pilarpilar pendidikan UNESCO di Sekolah Menengah Kejuruan Negeri 1 Tembilahan dengan persentase $\mathbf{6 6 , 3 7 \%}$ dikategorikan "Baik" berada pada interval 61-80\%.

Faktor-faktor yang mempengaruhi implementasi pilar-pilar pendidikan UNESCO di Sekolah Menengah Kejuruan Negeri 1 Tembilahan, diantaranya Faktor Pendukung, meliputi fasilitas sekolah yang memadai, latar belakang dan pengalaman guru yang beragam, pemahaman guru tentang pendekatan empat pilar pendidikan UNESCO .

Sedangkan faktor penghambat, meliputi beragamnya peserta didik, dan alokasi waktu yang terbatas. 


\section{REFERENSI}

Gre Publishing.

Aunurrahman. (2014). Belajar dan

Pembelajran. Bandung: Alfabeta.

Danim, S. (2010). Pengantar

Kependidikan. Bandung: Alfabeta.

Efendi, D. (2015). Dasar-Dasar Ilmu Pendidikan. Padang: Universitas Negeri Padang.

Hafid, A., Ahiri, A., \& Haq, E. (2014). Konsep Dasar Ilmu Pendidikan. Bandung: Alfabeta.

Hamdani. (2011). Strategi Belajar Mengajar. Bandung: CV Pustaka Setia.

Kemendikbud. (2018). UNESCO. https://kwriu.kemdikbud.go.id/unesc o/tentang-unesco/.

Kodir, A. (2011). Strategi Belajar Mengajar. Banfung: CV Pustaka Setia.

Pengembangan, M. P. (2015). Metode Penelitian dan Pengembangan. Bandung: Alfabeta.

Sukmadinata, N. S. (2012). Metode Penelitian Pendidikan. Bandung: PT. Remaja Rosdakarya.

Syafril, \& Zen, Z. (2007). Dasar-dasar Ilmu Pendidikan. Depok: Kencana.

Taniredja, T. (2016). Guru yang Profesional. Bandung: Alfabeta.

Wikipedia. (2019). Organisasi Pendidikan, Keilmuan, dan Kebudayaan Perserikatan BangsaBangsa. https://id.wikipedia.org/wiki/Organis asi_Pendidikan_Keilmuan_dan_Keb udayaan_Perserikatan_BangsaBangsa).

Yanti, F. A., \& dkk. (2018). Teori Aplikasi Model Cooperative Research Project Based Learning di Perguruan Tinggi. Yogyakarta: CV. 